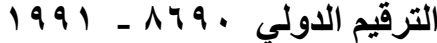

Website: http://jsci.utq.edu.iq

Email: utjsci@utq.edu.iq

\title{
Seroepidemiological Screening For Toxoplasmosis Within Unmarried Women In Basrah Province
}

\author{
Ghalib Noori AL-Mousawi* \\ * Primary health care department \\ Wafaa Sadoon Shani ** \\ **Biology department \\ College of Science - University of Basrah
}

\section{$\underline{\text { Abstract }}$}

Current study included Seroepidemiological Screening of 450 sera from unmarried women, within age ranged between (15 - 45) year by using IgG and IgM Enzyme Linked Immunosorbent Assay (ELISA) test. Sera collected from areas of Basrah province and from different classes ( students, officials and housewives ), and according to the primary health care department program the province was divided into eight sections .

Results documented that the prevalence rate of the disease in unmarred women in the whole province was $58 \%$ while the prevalence rates of sections was as follows : Sec I 63.2\%, Sec II 51.8\% , Al - Midayna 75\%, AI - Qurna 64\%, Al - Hartha 70\%, Shatt - al - Arab 55\%, Abu - al - Khaseeb $67.5 \%$ and $\mathrm{Al}$ - Zubair $36.3 \%$. The higher rate recorded in $\mathrm{Al}$ - Midayna and lower rate in $\mathrm{Al}$ - Zubair .

According to age group there is a significant difference $(\mathrm{P}<0.025)$ and the results showed that (15 - 19) year with the rate of infection $64.54 \%,(30-34)$ year with rate $60.7 \%,(35-39)$ year with rate $60 \%$, while the results upon sociodemographic data recorded that the housewives (all of them with low level of learning) represents rate $62.4 \%$ in comparison with students $45 \%$ and officials $44 \%$, with a significant differences $(\mathrm{P}<0.05)$.

\section{Introduction}

The intracellular protozoan Toxoplasma gondii is a wide speared opportunistic parasite of humans and animals ( Dubey and Beatti , 1988 ). Transmission from animals to humans occurs mainly through oocysts excreted in the feces of infected cats and meat products from farm animals contaminated with viable tissue cyst . although infection in immunocompetent humans is usually asymptomatic , toxoplasmosis may cause severe complications in immunocompromised individuals ( Israelski and Remington, 1993 ) .Toxoplasmosis has a global distribution since about $30 \%$ of the 
world population is infected and ( 20 60 ) \% of the United States and United kingdom are serologically positive, while in France it reached $80 \%$

( Alexander et al , 1998 ). The incidence of infection in humans and animals may vary in different parts of a country ( Baxter , 2002 ). The cause of these variations are not yet known but may be related to : environmental conditions, cultural habits, diet hygiene , eating habits, climate and cat contact in the case of the presence of high population of cats ( $\mathrm{Wu}$ and Gracia , 2005 ).

The socioeconomic factors as well as the geographic location also act on the incidence of infection ( Beamman et al. , 1998 ) .

Because there is no study related with prevalence of toxoplasmosis in unmarried women we try in present work to assess the prevalence of toxoplasmosis in unmarried women in Basrah province by making seroepidemiological screening, as well as study the relationship between the infection and some factors like age , location, job and level of learning .

\section{Materials and Methods}

\section{a - / Sample collection:}

Seroepidemiological screening was assessed by the collection of 450 blood samples from unmarried women aged ( $15-45$ ) years. The samples were collected from different sections of Basrah province, which were divided according to the primary health care system into eight sections these are : $\mathrm{Al}$ - Midayna, AI - Qurna , Al - Hartha , Shatt - al - Arab , Abu - al - Khaseeb , $\mathrm{Al}$ - Zubair and the two remaining sections which represents the center (Hay Al-Hussain , Al-Qibla and Al-
Ashar) and section.

The collected data from studied unmarried women included age , location, job and the level of learning . Sera obtained by centrifugation at 1500 rpm for $5 \mathrm{~min}$.

b - / Detection of anti - Toxoplasma IgG and IgM by ELISA :

Sera tested by Enzyme Linked Immunosorbent Assay for detection of $T$. gondii infection by evaluating anti Toxoplasma IgG and IgM .

Anti - Toxoplasma IgG and IgM detected by using ELISA kit of Euroimmune company from Germany .

The concentration of IgG and IgM were calculated by using a standard curve for six standard which supplemented with a kit .

In the case of $\operatorname{IgG}$, and according to the data supplemented with a kit.

$<8 \mathrm{IU} / \mathrm{ml}$ Negative

$\geq 8-<11 \mathrm{IU} / \mathrm{ml}$ Borderline

$\geq 11 \mathrm{IU} / \mathrm{ml}$ Positive

While the IgM

$<0.8$ Negative

$\geq 0.8-<1.1$ Borderline

$\geq 1.1$ Positive .

\section{c - / Statistical analysis :}

Data were analyzed by using the Statistical Package for Social Science ( SPSS ) which include statistical tables, percentages, graphical presentation, chi square and level of significance ( Walpole, 1982 ).

\section{$\underline{\text { Results }}$}

The results of seroepidemiological screening of toxoplasmosis in unmarried women which was done for the first time in Basrah province showed that out of 450 sera examined 261 ( $58 \%$ ) were infected with $T$. gondii whereas the remaining 189 ( $42 \%$ ) sera did not had 
any infection or did not show a positive differences $(\mathrm{P}<0.001)$. ( Table 1$)$. titer in ELISA test with high significant

Table ( 1 ) : Distribution of toxoplasmosis in unmarried women in Basrah province

\begin{tabular}{||c|c|c|c||}
\hline $\begin{array}{c}\text { RESUL T OF } \\
\text { ELISA TEST }\end{array}$ & $\begin{array}{c}\text { NUMBER OF } \\
\text { EXAM } \\
\text { WOMEN }\end{array}$ & $\begin{array}{c}\text { PER CENTAGE OF } \\
\text { INFE CTION ( \% ) }\end{array}$ & CHI SQUARE \\
\cline { 1 - 3 } Positive & 261 & 58 & \multirow{2}{*}{11.520} \\
\hline Negative & 189 & 42 & \\
\hline Total & 450 & 100 & \\
\hline
\end{tabular}

From 261 positive sera only 251 ( $96.16 \%$ ) sera showed a positive titer of $\mathrm{IgG}$ and 10 ( $3.84 \%$ ) showed positive IgM titer .

The high level of prevalence was recorded in $\mathrm{Al}$ - Midayna ( $75 \%$ ) and $\mathrm{Al}$ - Hartha ( $70 \%$ ) with significant differences ( $\mathrm{P}<0.023)$, while $\mathrm{Al}-$ Zubair showed a low level of infection ( $36.3 \%$ ) . Other sections ( No. 36 , No. 36, Abu - al - Khasseb , Al - Qurna and Shatt -al - Arab ) recorded different prevalence rates ( $63.2 \%, 51.8 \%, 67.5$ $\%$ and $55 \%$ ) respectively ( Table 2 ).

Table ( 2 ) : Distribution of the positive cases of toxoplasmosis ( according to sections ) in the sera of 450 unmarried women in Basrah province

\begin{tabular}{|c|c|c|c|c|c|}
\hline & $\begin{array}{c}\text { TESTED } \\
\text { SAMPLES }\end{array}$ & $\begin{array}{c}\text { POSITIVE } \\
\text { SERA }\end{array}$ & PERCENT AGE & $\%$ & SQUARE \\
\hline No. - $3-$ & 95 & 60 & 23 & 63.2 & \multirow{9}{*}{0.023} \\
\hline No. - 3 - & 85 & 44 & 17 & 51.8 & \\
\hline $\begin{array}{c}\text { Abu-al- } \\
\text { Khasseb }\end{array}$ & 40 & 27 & 10.3 & 67.5 & \\
\hline A1-Qurna & 50 & 32 & 12.2 & 64.0 & \\
\hline $\begin{array}{c}\text { A1- } \\
\text { Midayna }\end{array}$ & 40 & 30 & 11.5 & 75.0 & \\
\hline A1-Zabair & 80 & 29 & 11 & 36.3 & \\
\hline $\begin{array}{c}\text { Shatt }-\mathrm{al}- \\
\text { Arab }\end{array}$ & 20 & 11 & 4 & 55.0 & \\
\hline A1 - Hartha & 40 & 28 & 11 & 70.0 & \\
\hline Total & 450 & 261 & 99.9 & 60.35 & \\
\hline
\end{tabular}

According to age, results of seroepidemiological screening revealed 
that there were high significant differences $(\mathrm{P}<0.025)$ in age groups $(15-19)$ year and ( $40-44)$ year with prevalence rates $64.54 \%$ and $20 \%$ respectively ( Table, 3 ) .

Table ( 3 ) : Distribution of the positive cases of toxoplasmosis ( according to age groups ) of 450 women from Basrah province

\begin{tabular}{|c|c|c|c|c|c|c|}
\hline $\begin{array}{c}\text { AGE } \\
\text { GROUPS }\end{array}$ & $\begin{array}{c}\text { NO. OF } \\
\text { TESTED } \\
\text { SAMPLES }\end{array}$ & $\begin{array}{c}\text { NO. OF } \\
\text { POSITIVE } \\
\text { CASES }\end{array}$ & $\begin{array}{c}\text { MEAN } \\
\text { PERCEN } \\
\text { TAGE }\end{array}$ & $\begin{array}{c}\text { PREVALENCE } \\
\%\end{array}$ & $\begin{array}{c}\text { CHI } \\
\text { SQUARE }\end{array}$ & SIG. \\
\hline $15-19$ & 110 & 71 & 27 & 64.54 & \multirow[t]{7}{*}{30.00} & \multirow[t]{7}{*}{0.025} \\
\hline $20-24$ & 94 & 54 & 21 & 57.44 & & \\
\hline $25-29$ & 125 & 65 & 25 & 52 & & \\
\hline $30-34$ & 61 & 37 & 12.6 & 60.7 & & \\
\hline $35-39$ & 55 & 33 & 14.1 & 60 & & \\
\hline $40-44$ & 5 & 1 & 0.3 & 20 & & \\
\hline Total & 450 & 261 & 100 & 58 & & \\
\hline
\end{tabular}

Table ( 4 ) demonstrated that the toxoplasmosis was present in a high percentage in housewives ( $62.4 \%$ ) in comparison with the other two groups students ( $45 \%$ ) and officials ( $44 \%$ ) with significant differences $(\mathrm{P}<0.05)$.

Table ( 4 ) : Distribution of the positive cases of toxoplasmosis ( according to sociodemographic state ) of 450 women from Basrah province

\begin{tabular}{|c|c|c|c|c|c|c|}
\hline $\begin{array}{c}\text { SOCIODEMOGRA } \\
\text { PHIC STATE }\end{array}$ & $\begin{array}{c}\text { NO. OF } \\
\text { TESTED } \\
\text { SAMPLES }\end{array}$ & $\begin{array}{l}\text { NO. OF } \\
\text { POSITIVE } \\
\text { CASES } \\
\end{array}$ & $\begin{array}{l}\text { MEAN } \\
\text { PERCE } \\
\text { NTAGE }\end{array}$ & $\begin{array}{l}\text { PREVALE } \\
\text { NCE } \%\end{array}$ & $\begin{array}{c}\text { CHI } \\
\text { SQUARE }\end{array}$ & SIG. \\
\hline $\begin{array}{l}\text { Housewives (all of } \\
\text { them with a low level } \\
\text { of learning) }\end{array}$ & 340 & 212 & 81.2 & 62.4 & \multirow[t]{4}{*}{4.542} & 0.05 \\
\hline $\begin{array}{l}\text { Students } \\
\text { (college and Inst.) }\end{array}$ & 60 & 27 & 10.4 & & & \\
\hline Officials & 50 & 22 & 8.4 & & & \\
\hline Total & 450 & 261 & 100 & 58.0 & & \\
\hline
\end{tabular}

\section{Discussion}

Most studies on toxoplasmosis in Basrah have been conducted on the general population or some groups like aborted women ; so the current study which cross sectional, was conducted on unmarried women in Basrah province . 
According to the classification of the province into sections, the high prevalence rate was recorded in $\mathrm{Al}$ Midyna $75 \%$ while a lower prevalence in $\mathrm{Al}$ - zubair $36.3 \%$. this variation may be due to many factors, like the climatic changes which have an important influence on the epidemiology of most infectious disease of humans and tend to induce regular cyclic fluctuations in the prevalence and intensity of parasitic infections (Cox ,1982) .

Geographically, areas of Basrah are different in structure of soil and climatic changes. The soil of the most area like Al - Zubair is gravel, sandy and its weather characterized by a decrease humidity and an increase in temperature versus other areas with a soil from that is clay and loamy and its weather is differentiated by a rise in humidity ( $\mathrm{Al}-$ Assdi , 1998 ), and this difference in soil and humidity affect the viability of oocysts in deposit cat feces ( Wu \& Garcia , 2005 ) .

The high rate of prevalence in section I $63.2 \%$ was due to the low socioeconomic status of the area and its bad sanitation, while the rates in $\mathrm{Al}$ Midayna , Abu - al - Khasseb , Al Qurna and $\mathrm{Al}$ - Hartha were $75 \%, 67.5$ $\%, 64 \%$ and $70 \%$ respectively, because these sections are farming areas and with animal intensive ; people also consume unpasturised milk and dairy products, with a number of stray cats and dogs , illegal slaughtering and in appropriate waste disposal ( Seimenis , 1998 ). Besides, these sections are situated near marshes and rivers leading to usage of contaminated water for drinking and washing. In addition to that , we have great changes that took place in the last years especially the increasing urbanization most of which is inadequately planned. The results ( related to sections ) are similar to those obtained by Yacoub et al. ( 2006 ), while the result of all of the province 58 $\%$, is close to the rate $60.2 \%$ reported by Abbas et al. ( 2004 ) in Baghdad among aborted women. But, when compare our results with neighboring countries, in Kuwait and Iran the rates are $66.9 \%, 74.6 \%$ respectively ( Iqbal and Khalid , 2007 \& Shanis et al. 2006) .

According to age group , socioepidemiological screening revealed a high prevalence rate of toxoplasmosis in three age range groups $(15-19)$ year , ( $30-34$ ) year and $(35-39)$ year, was $64.54 \%, 60.7 \%$ and $60 \%$ respectively, and this may be related to fact that after sanctions were imposed on Iraq in 1990 and three wars Iraq was engaged in , this lead to the degradation of infrastructure ( especially power electricity and water supply ), and this may be produced bad health conditions which are represented by increase of malnutrition among children and women with a sever anemia as well as rise in food - borne and water - borne diseases ( Popal , 2000 ) .

As for the socioeconomic data of the seroepidemiological study showed that toxoplasmosis prevalence was higher in housewives in comparison with students and officials. The most acceptable explanation for these results is that most of the housewives ( all of them with a low educational level ) lack the important information about the disease, gardening and ownership of pets ( dogs , cats , birds ) .

\section{$\underline{\text { References }}$}

Abbas , M. ; Niazi , A. and Habib , M. ( 2004 ). Specific IgG avidity testing in diagnosis of acute toxoplasmosis among women with history of abortion . Iraqi J. Med. Sci. ; 3 ( 2 ) : $144-147$. 
AL - Assadi , K.A.W. ( 1998 ) . The influence of climatic factors on basis industries in

Basrah Governorate and their effects on pollution of the environment . Ph. D. Thesis , College of Arts , Geography , Basrah University .

Alexander , J. , Jebbari , H. , Bluethmann , H. and Roberts , C.W. ( 1998 ). The role of IL -4 in adult acquired and congenital toxoplasmosis . J. Parasitol. $28: 113-120$.

Baxter , A. ( 2002 ). What is T. gondii ? www.Pagewise home . Health and fitness .

Beumann , M.H. ; Maccabe , R.E. and Remington, J.S. ( 1995 ) . T. gondii in ; Mendell , G.L. , Bennette , J.E. , and Dolin , R. eds. Principle and Practice of infectious disease. $5^{\text {th }}$ ed. Churchill Livingston, New York . P : 55-57.

Cox , F.E.G. ( 1982 ) . Modern parasitology . $1^{\text {st }}$ ed. B. W. SC. Pub. London . pp : $245-248$.

Dubey , J.P. and Beattie , C.P. ( 1988 ). Toxoplasmosis of animals and man. cRc Press , Boca Raton, Fla.

Iqbal , J. and Khalid, N. ( 2007 ) . Detection of acute $T$. gondii infection in early pregnancy by IgG avidity and PCR analysis . J. Medi. Microb. ; 56 ( 11 ) : $1495-1499$.
Israelski, D.M. and Remington, J.S. ( 1993 ). Toxoplasmosis in the non - AIDS - immunocompromised host . Curr. Clin. Trop. Infect. Dis. $13: 322-356$.

Popal , G.R. ( 2000 ) . Impact of sanction on the population of Iraq . E. M. H. J. 6 ( 4 ) : $791-795$.

Seimenis , A. ( 1998 ). Zoonosis : A social and economic burden E.M.H.J. ; 4 ( 2 ) : 220 - 222 .

Shanis , M. ; Agin , A. ; Daryain , A. ; Ziaei , H. and Khalilian, A. ( 2006 ) . Serological survey of $T$. gondii in women referred to Medical Health Lad. Before marriage , North of Iran . Int. J. Molec. Med. Adv. Sci. : 2 ( 2 ) : $134-137$.

Walpole , R.E. ( 1982 ) . Introduction to statistics $3^{\text {rd }}$ edition. Collier Macmillan Publishing Co. 219 .

Wu , L. and Gracia , R.A. ( 2005 ) . Toxoplasmosis article. eMedicine section $1-11$.

Yacoub , A.A-H. ; Bakr, S. ; Hameed ; A-M. , AL - Thamiry A. and Fartoci , M. J. ( 2006 ) . Seroepidemiology of selected zoonotic infections in Basrah . EMHJ 12 . 
التحري المصلي الوبائي عن داء المقوسات ضدن النساء غير المنزوجات في محافظة البصرة

$$
\text { * *قالب نوري الموسوي }
$$

\section{الخلاصة}

تضمنت الدر اسة الحالية التحري المصلي الوبائي لـ ـ0 ؛ مصل من النساء غير المتزوجات تتر اوح أعمار هن

(10 ـ 0 ؛ ) سنة باستخدام فحص الامتصاصية المناعيـة المرتبطة بـالإنزيم من خلال قياس الكلوبيولين المنـاعي جمعت المصول من مناطق مختلفة في محافظة البصرة ومن شر ائح مختلفة في المجتمع ( طالبات IgM و IgG ، ربات بيوت ، موظفات ) ـ وقد قسمت المناطق إلى ثمانية قطاعات اعتماداً على برنامج معمول بهِ في قسم الرعايـة الصحية الأولية في البصرة ـ أكدت النتائج أن معدل انتشار المرض في النساء غير المتزوجات في مجمل المحافظـة

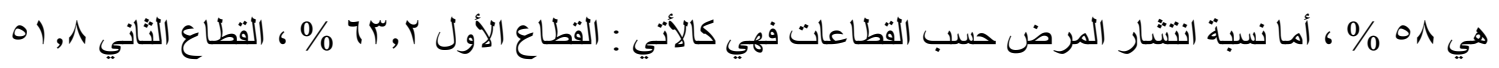

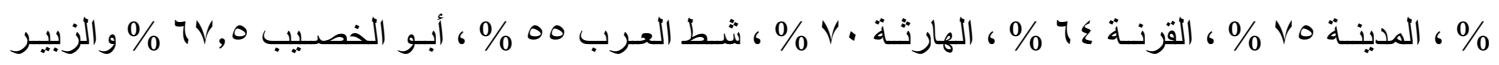
r, r \% حيث سجلت أعلى نسبة في المدينة و أقل نسبة في الزبير .

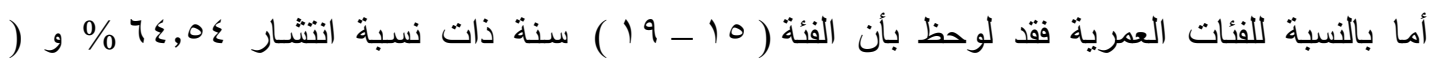

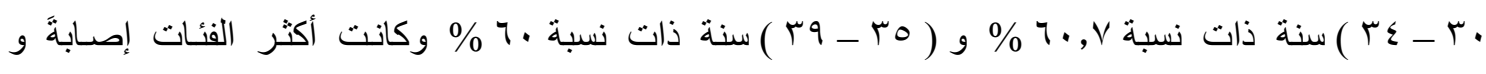
بفارق معنوي ( 0.025 > P ) ـ بينمـا سـلت الدراسـة الاجتماعيـة والإحصـائية أن ربـات البيوت ( ذوات التعليم

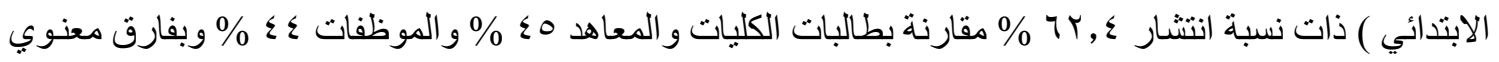

